\title{
Impact of Psychological Capital on Well-Being of Management Students
}

\author{
Vikas Gautam ${ }^{1}$ (D), Sombala Ningthoujam², Teena Singh ${ }^{3}$ \\ ${ }^{1}$ Department of Marketing \& Strategy, ICFAI Business School Hyderabad, Hyderabad, India \\ ${ }^{2}$ New Delhi Institute of Management, New Delhi, India \\ ${ }^{3}$ Head of Department of International Relations, New Delhi Institute of Management, New Delhi, India \\ Email: vika sgautam@ibsindia.org, vgautam78@gmail.com, sombala@rediffmail.com, n.sombala@ndimdelhi.org, \\ teena.singh@ndimdelhi.org
}

How to cite this paper: Gautam, V., Ningthoujam, S. and Singh, T. (2019) Impact of Psychological Capital on Well-Being of Management Students. Theoretical Economics Letters, 9, 1246-1258.

https://doi.org/10.4236/tel.2019.95081

Received: April 23, 2019

Accepted: May 14, 2019

Published: May 17, 2019

Copyright $\odot 2019$ by author(s) and Scientific Research Publishing Inc. This work is licensed under the Creative Commons Attribution International License (CC BY 4.0).

http://creativecommons.org/licenses/by/4.0/

\begin{abstract}
We investigated the impact of Psychological Capital on the wellbeing of postgraduate management students. The relationship between two second order reflective constructs namely; Psychological Capital (hope, resilience, optimism, self-efficacy); well-being (positive health, distress) was tested by using higher order structural equation modeling with the help of IBM AMOS 20.0. Our study results confirmed positive significant impact of Psychological Capital on the wellbeing of postgraduate management students. We strongly recommend that instructors, counselors, management and administration must work collectively on conceptualizing, planning, and execution of educational and counseling activities/programs that aim cultivate students' sustainable psychological resources like Psychological Capital to facilitate constructive psychological functioning in academics. The study results are based on 109 postgraduate students from a privately owned business school.
\end{abstract}

\section{Keywords}

Psychological Capital, Hope, Resilience, Optimism, Self-Efficacy, Well-Being, Positive Health, Distress, Structural Equation Modeling

\section{Introduction}

Academic demands vary across educational institutions and success in the endeavors remains aspiration for all the students. In this context, teaching community is always concerned about the academic success optimization of students. Psychological capital facilitates positive student outcomes [1]. According to [2] "Psychological capital is a state-like positive motivational condition that arises from one's endorsement of hope, optimism, resilience, and self-efficacy". 
Further, [3] defined Psychological capital as "positive appraisal of circumstances and probability for success based on motivated effort and perseverance" (p. 550).

Literature has supported four positive psychological characteristics of Psychological capital namely; Hope [4], Optimism [5], Resilience [6] Self-Efficacy [7]. According to [4], hope is related to mindset which encompasses enthusiasm to achieve chosen goals. Optimism is related to expectations that decent and constructive things will take place in the future time [5]. [6] explained resilience as one's competency to meritoriously acclimatize it when facing prominent hardship and negative situations. Self-Efficacy means an individual's perceived capability to achieve explicit behaviors [7].

Literature has witnessed relative impact of Psychological Capital on distinctive positive outcomes. Psychological capital had confirmed significant positive correlation with organizational citizenship behavior [8]; work engagement [9]; well-being [10]; job satisfaction and organizational commitment [11].

Even though there are the promising benefits of Psychological Capital in the organizational context, scanty is known about the cherished effects of Psychological Capital on positive educational outcomes specifically in Asian academic settings. [1] and [12] investigated the psychological benefits of Psychological Capital in Hong Kong and Chinese students, but culture is not uniform across all Asian countries.

Results of the current study may also offer prominent comprehensions regarding the applicability of Western derived multidimensional Psychological Capital construct in Asian socio-cultural societies. Examining the impending value of Psychological Capital in augmenting positive psychological outcomes would contribute to the existent literature on the appropriate consequences of Psychological Capital particularly in the academic setting. As it is very well-known fact that Psychological Capital construct was initially envisioned for employees in the organization [2], there are practical explanations to debate that Psychological Capital can also be pertinent for student community. The problem of mental health besides physical health illness among college students is an important public health issue [13]. [14] defined good mental health as a state of well-being in which the individual realizes his or her own abilities, can cope with the normal stresses of life, can work productively and fruitfully, and is able to make a contribution to his or her community (p. 12).

Initially, educational settings can be considered as an indispensable organization that can contour students' occupational-related deeds like employees' workplace. Further, the activities like attending lectures, completing classwork, working on group project, role playing during sessions, preparing and submitting various assignments in time etc. may be considered as work [12]. In this context, understanding relationship between Psychological Capital and well-being of students may expand the literature on positive educational practices.

Hence, the main objective of the current study was to evaluate the useful role of Psychological Capital among management students. Explicitly, we examined the relation of Psychological Capital with well-being, a relevant student outcome 
with the help of structural model.

\section{The Review of Literature}

\subsection{Relationship between Psychological Capital and Well-being}

According to the student well-being model [15], thinking and feeling are said to interactively enhance wellbeing; positive thoughts lead to positive feelings and vice-versa. However, both thinking and feeling are considered essential to student wellbeing separately as well. Psychological Capital and its constituents (hope, efficacy, resilience, and optimism) are said to lead to positive appraisals of one's past, present and future, in general and in specific life domains. It is suggested that Psychological Capital might imbue positivity into students' thoughts in general and in particular about their school life, thus contributing to wellbeing. Student wellbeing has been defined as "A sustainable state of positive mood and attitude, resilience and satisfaction with self, relationships and experiences at school [16]".

Additionally, the positive appraisal mechanism of Psychological Capital might lead to positive evaluations of students' experiences at school, and thus contribute toward increasing their wellbeing. In yet another mechanism by [3], wellbeing is said to be shaped by memories of events in one's life. Since, Psychological Capital it has been proposed makes it easier to attend to, interpret and retain domain-specific experiences such that it adds to wellbeing. Psychological Capital is also stated to support wellbeing by reducing one's negativity bias. Many empirical investigations have affirmed the linkage between Psychological Capital and wellbeing of students [3] [17].

According to [18], resilience skills like optimistic, helpful thinking skills, adaptive distancing skills, humor and seeking assistance skill are important for both academic and personal success in school and in life. Resilience may be defined as 'the ability to persist, cope adaptively and bounce back after encountering change, challenges, setback, disappointments, difficult situations or adversity and to return to a reasonable level of wellbeing for interpreting adjusting to negative life, an optimistic approach is needed for developing resilience skill' [19].

\subsection{Wellbeing as a Predictor of Psychological Capital}

Some researchers have studied wellbeing as a predictor of one's Psychological Capital. [20] had found overall wellbeing to contribute significant unique variance to overall Psychological Capital. Studying two dimensions of wellbeing, eudaimonic and hedonic, [21] also found one's Psychological Capital to predict variance in their eudaimonic work wellbeing.

Psychological Capital also acts as a mediator in relationships between certain variables and wellbeing. For example, among leaders (CEOs, presidents and managers) and entrepreneurs, [22] found mindfulness to be negatively associated with various dysfunctional outcomes (such as anxiety and depression), with Psy- 
chological Capital playing a mediating role in the relationship. Further, Psychological Capital fully mediates the relationship between empowering leadership and psychological wellbeing of employees [23].

\subsection{Wellbeing as a Consequence of Psychological Capital}

Various researchers have studied the role of Psychological Capital in determining wellbeing levels of individuals. [10] found Psychological Capital to not only be related to two measures of wellbeing, but also to add small, significant variance in them over time. In a different population of Chinese employees, [24] found Psychological Capital to be significantly and positively associated with work wellbeing measured after a time period of five months. More specifically, two components of Psychological Capital namely, self-efficacy and resilience, have been identified as significant predictors of employee wellbeing [25].

\section{Hypothesis of the Study}

$\mathrm{H}_{0}$ : Psychological capital does not impact Well Being of Management Students.

$\mathrm{H}_{1}$ : Psychological capital significantly impacts Well-Being of Management Students.

\section{Research Methodology}

\subsection{Data and Sample}

The participants in this study were postgraduate students studying business in their first semester at a privately owned business school located in New Delhi, India. Students were enrolled in a PGDM (Post Graduate Diploma in Management) Program (approved by All India Council for Technical Education, Delhi) in which data was collected for this study. Students completed a structured questionnaire based survey in class in which they rated measures of Psychological Capital (sub constructs; hope, resilience, optimism, self-efficacy) and their wellbeing (sub constructs; positive health, distress). A total number of 109 completed questionnaires were collected with the help of simple random sampling technique to achieve study objectives.

\subsection{Measures}

\subsubsection{Psychological Capital}

Psychological capital was self-rated by management students using an adapted version of the 12-item short-scale developed by [3]. In line with [26] the items were adapted to suit the management education context. Consistent with extant literature, we used a 5 -point Likert's scale (where $1=$ strongly disagree and $5=$ strongly agree). The measure was treated as a second-order construct where items loaded onto their respective sub-constructs namely; hope (4 items), resilience (3 items), optimism ( 2 items), and self-efficacy ( 3 items). 


\subsubsection{Wellbeing}

Wellbeing was self-rated by management students using 12 -item research instrument adopted from [27] on a 4-point Likert's scale (where $1=$ never, $2=$ seldom, $3=$ sometimes and $4=$ often). Sample items like "Have you recently been able to concentrate on whatever you're doing?" "Have you recently been feeling reasonably happy, all things considered?".

\section{Data Analysis}

\subsection{Demographic Profile}

It can be seen from Table 1 that sample included good mix of male (47.70\%) and female (52.30\%) management students.

Table 2 showed the age groups of respondents ranging from 20 years to above 25 years.

It can be seen from Table 3 that all the study constructs passed the test of reliability. The Cronbach's alpha values ranged from 0.754 to 0.919 , which lies above the threshold level recommended by [28]. Hence, the study measurement scales passed the reliability test.

\section{Confirmatory Factor Analysis (Figure 1) (Table 4, Table 5)}

Confirmatory Factor Analysis (CFA) model with two second order constructs (one with 4 first order constructs and other with 2 first order constructs) had a total of 58 distinct parameters and 300 distinct sample moments. The model was identified and a minimum was achieved. The CFA results showed that all the study parameters were practicable and standard errors in acceptable limits. Statistical significance of parameter estimates was established as critical ratio ( $t$-value) in each case was greater than threshold limit of 2.58. It can be seen from Table 2 that all model fit indices exceeded the recommended threshold levels [30] [31]. Hence the measurement model of the study was confirmed.

\section{Structural Equation Modeling (SEM) Results (Figure 2) (Table 6)}

Structural model with two second order constructs with cause and effect relationship had a total of 58 distinct parameters and 300 distinct sample moments. A minimum was achieved with model identification. All the study parameters were practicable and standard errors in acceptable limits. Statistical significance of parameter estimates was established as critical ratio ( $t$-value) in each case was greater than threshold limit of 2.58. It is evident from Table 3 that all model fit

Table 1. Descriptive statistics (gender).

\begin{tabular}{ccccc}
\hline \multicolumn{5}{c}{ Gender } \\
\hline & Frequency & Percent & Valid Percent & Cumulative Percent \\
\hline Male & 52 & 47.7 & 47.7 & 47.7 \\
Female & 57 & 52.3 & 52.3 & 100.0 \\
Total & 109 & 100.0 & 100.0 & \\
\hline
\end{tabular}


Table 2. Descriptive statistics (age).

\begin{tabular}{ccccc}
\hline \multicolumn{5}{c}{ Age } \\
\hline Age Groups (In Years) & Frequency & Percent & Valid Percent & Cumulative Percent \\
\hline $20-22$ & 61 & 56.0 & 56.0 & 56.0 \\
$23-25$ & 45 & 41.3 & 41.3 & 97.2 \\
$>25$ & 3 & 2.8 & 2.8 & 100.0 \\
Total & 109 & 100.0 & 100.0 & \\
\hline
\end{tabular}

Table 3. Reliability analysis results.

\begin{tabular}{cccc}
\hline S.N. & Construct & No. of Items & Cronbach's Alpha \\
\hline 1 & Hope & 4 & 0.919 \\
2 & Resilience & 3 & 0.884 \\
3 & Optimism & 2 & 0.872 \\
4 & Self-Efficacy & 3 & 0.902 \\
5 & Psychological Capital & 12 & 0.962 \\
6 & Positive Health & 6 & 0.770 \\
7 & Distress & 6 & 0.754 \\
8 & Well Being & 12 & 0.795 \\
\hline
\end{tabular}

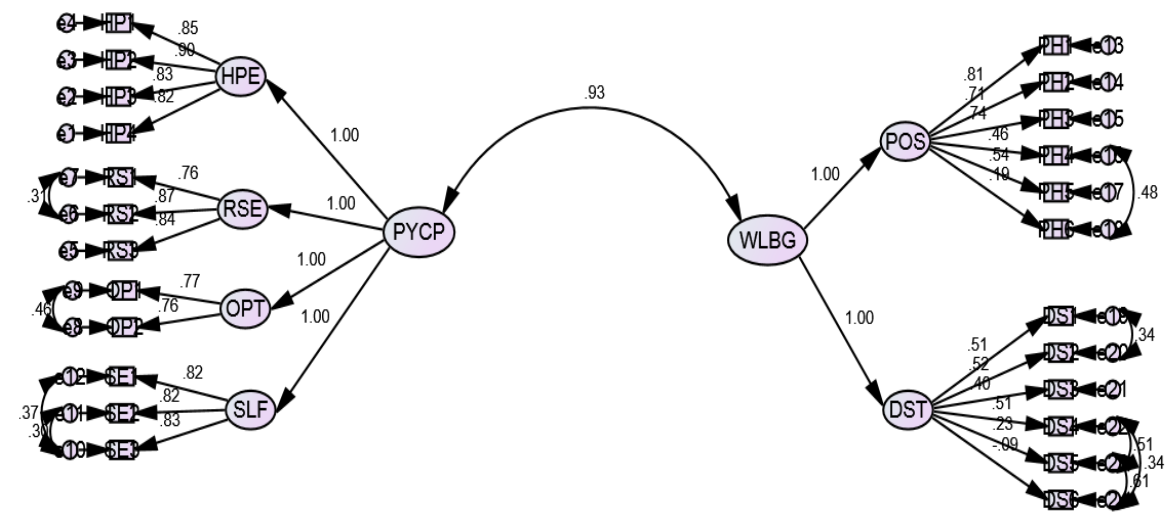

Figure 1. Confirmatory factor analysis results.

indices exceeded the recommended levels [30] [31]. Hence the structural model was found fit as per the given data.

\subsection{Hypothesis Testing (Table 7)}

It can be seen from the second order SEM results that Psychological Capital had positive significant impact on Well Being $(\beta=0.934, p<0.000)$. Therefore, the study hypothesis was supported at 5 percent level of significance.

\section{Discussion and Conclusion}

The current research tested predictions about the role of Psychological Capital in influencing management students' subjective well-being. The study results 
Table 4. Regression weights: (Group number 1-Default model).

\begin{tabular}{|c|c|c|c|c|c|c|c|}
\hline & & & Estimate & S.E. & C.R. & $p$ & Label \\
\hline HPE & $<---$ & PYCP & 1.000 & & & & \\
\hline SLF & $<---$ & PYCP & 1.156 & 0.110 & 10.540 & $* * *$ & par_19 \\
\hline OPT & $<---$ & PYCP & 1.069 & 0.115 & 9.295 & $* * *$ & par_20 \\
\hline RSE & $<---$ & PYCP & 1.172 & 0.109 & 10.753 & $* * *$ & par_21 \\
\hline POS & $<---$ & WLBG & 1.000 & & & & \\
\hline DST & $<---$ & WLBG & 0.647 & 0.121 & 5.363 & $* * *$ & par_31 \\
\hline HP4 & $<---$ & HPE & 1.000 & & & & \\
\hline HP3 & $<---$ & HPE & 1.108 & 0.105 & 10.535 & $* * *$ & par_1 \\
\hline HP2 & $<---$ & HPE & 1.265 & 0.106 & 11.976 & $* * *$ & par_2 \\
\hline HP1 & $<---$ & HPE & 1.326 & 0.122 & 10.900 & $* * *$ & par_3 \\
\hline RS3 & $<---$ & RSE & 1.000 & & & & \\
\hline RS2 & $<---$ & RSE & 1.108 & 0.095 & 11.675 & $* * *$ & par_4 \\
\hline RS1 & $<---$ & RSE & 0.884 & 0.093 & 9.552 & $* * *$ & par_5 \\
\hline OP2 & $<---$ & OPT & 1.000 & & & & \\
\hline OP1 & $<---$ & OPT & 0.973 & 0.084 & 11.544 & $* * *$ & par_6 \\
\hline SE3 & $<---$ & SLF & 1.000 & & & & \\
\hline SE2 & $<---$ & SLF & 0.909 & 0.073 & 12.472 & $* * *$ & par_7 \\
\hline SE1 & $<---$ & SLF & 0.905 & 0.068 & 13.226 & $* * *$ & par_8 \\
\hline PH1 & $<---$ & POS & 1.000 & & & & \\
\hline PH2 & $<---$ & POS & 0.913 & 0.113 & 8.079 & $* * *$ & par_9 \\
\hline PH3 & $<---$ & POS & 0.988 & 0.117 & 8.451 & $* * *$ & par_10 \\
\hline PH4 & $<---$ & POS & 0.603 & 0.125 & 4.836 & $* * *$ & par_11 \\
\hline PH5 & $<---$ & POS & 0.642 & 0.111 & 5.798 & $* * *$ & par_12 \\
\hline PH6 & $<---$ & POS & 0.236 & 0.125 & 1.879 & 0.060 & par_13 \\
\hline DS1 & $<---$ & DST & 1.000 & & & & \\
\hline DS2 & $<---$ & DST & 1.049 & 0.203 & 5.165 & $* * *$ & par_14 \\
\hline DS3 & $<---$ & DST & 0.813 & 0.233 & 3.485 & $* * *$ & par_15 \\
\hline DS4 & $<---$ & DST & 1.080 & 0.261 & 4.141 & $* * *$ & par_16 \\
\hline DS5 & $<---$ & DST & 0.486 & 0.227 & 2.138 & 0.033 & par_17 \\
\hline DS6 & $<---$ & DST & -0.206 & 0.245 & -0.840 & 0.401 & par_18 \\
\hline
\end{tabular}

showed full support on the hypothesis $\left(\mathrm{H}_{1}\right)$ as the path from Psychological Capital to student well-being was positive and highly significant. This suggests that students who embrace combination of hope, resilience, optimism, and self-efficacy 
Table 5. Goodness-of-fit indices.

\begin{tabular}{|c|c|c|c|}
\hline S. N. & Goodness of Fit Index & Value & $\begin{array}{c}\text { Acceptable } \\
\text { Threshold Value }\end{array}$ \\
\hline 1 & CMIN & 391.806 & - \\
\hline 2 & Df (Degrees of Freedom) & 242 & - \\
\hline 3 & $\mathrm{CMIN} / \mathrm{DF}$ & 1.619 & good if $<3$ \\
\hline 5 & IFI (Incremental Fit Index) & 0.920 & good if $\geq 0.90$ \\
\hline 6 & TLI (Tucker-Lewis Index) & 0.907 & good if $\geq 0.90$ \\
\hline 7 & CFI (Comparative fit Index) & 0.919 & good if $\geq 0.90$ \\
\hline 8 & $\begin{array}{c}\text { RMSEA (Root Mean Square Error of } \\
\text { Approximation) }\end{array}$ & 0.076 & good if $<0.08$ \\
\hline 9 & RMR (Root Mean Squared Residual) & 0.076 & good if $<0.08$ \\
\hline 10 & $\begin{array}{l}\text { ECVI (Expected Cross } \\
\text { Validation Index) }\end{array}$ & $\begin{array}{c}\text { Default Model }=4.706 \\
\text { ECVI value for Saturated } \\
\text { Model }=5.556 \\
\text { ECVI value for Independence } \\
\text { Model }=20.087\end{array}$ & $\begin{array}{l}\text { Default Model should } \\
\text { have least ECVI value }\end{array}$ \\
\hline
\end{tabular}

Source: Author compilation [29].

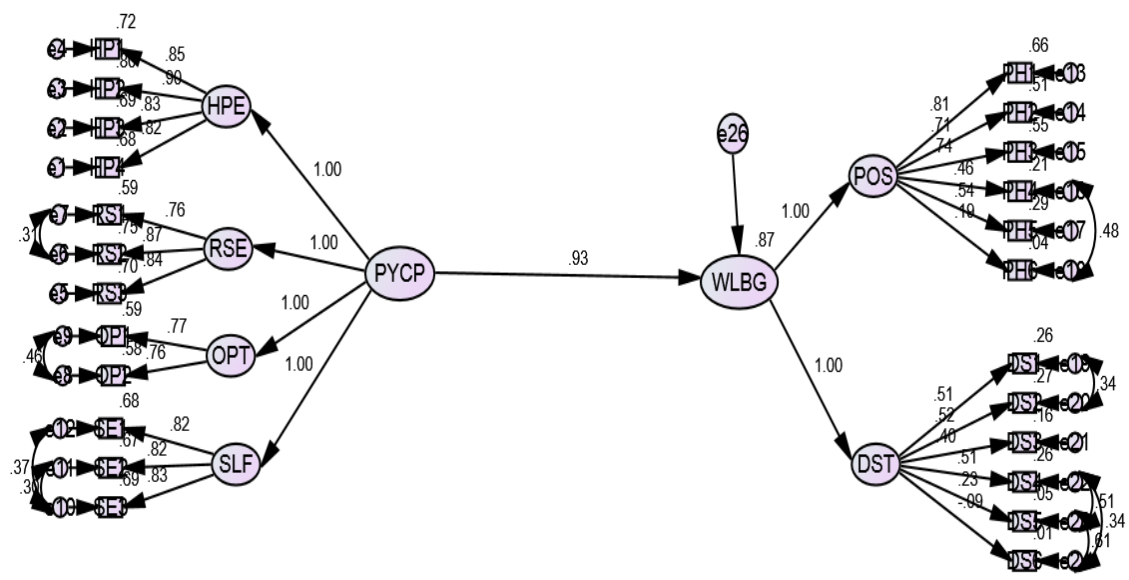

Figure 2. Study model.

may enthusiastically participate in innumerable classroom chores and feel happy in involving across various academic activities.

Our study results are consistent with the work done by [12] with one single difference that we conducted study on postgraduate management students, whereas they conducted study among undergraduate students. We found positive association between Psychological Capital and well-being outcomes. These results infer that commendation of multiple psychological resources in the form of hope, resilience, optimism, and self-efficacy may be linked to greater well-being of students with reference to positive health and distress.

These study results substantiated with the present literature on the advantageous role of Psychological Capital on well-being indices [1] [10] [32]. Though, our study addressed significant gaps on the relationship of Psychological Capital 
Table 6. Goodness-of-fit indices.

\begin{tabular}{|c|c|c|c|}
\hline S. N. & Goodness of Fit Index & Value & $\begin{array}{c}\text { Acceptable Threshold } \\
\text { Value }\end{array}$ \\
\hline 1 & CMIN & 391.806 & - \\
\hline 2 & Df (Degrees of Freedom ) & 242 & - \\
\hline 3 & CMIN/DF & 1.619 & good if $<3$ \\
\hline 4 & IFI (Incremental Fit Index) & 0.920 & good if $\geq 0.90$ \\
\hline 5 & TLI (Tucker-Lewis Index) & 0.907 & good if $\geq 0.90$ \\
\hline 6 & CFI (Comparative fit Index) & 0.919 & good if $\geq 0.90$ \\
\hline 7 & $\begin{array}{l}\text { RMSEA (Root Mean Square } \\
\text { Error of Approximation) }\end{array}$ & 0.076 & good if $<0.08$ \\
\hline 9 & $\begin{array}{c}\text { RMR (Root Mean Squared } \\
\text { Residual) }\end{array}$ & 0.063 & good if $<0.08$ \\
\hline 10 & $\begin{array}{l}\text { ECVI (Expected Cross } \\
\text { Validation Index) }\end{array}$ & $\begin{array}{c}\text { Default Model }=4.702 \\
\text { ECVI value for Saturated } \\
\text { Model }=5.556 \\
\text { ECVI value for Independence } \\
\text { Model }=20.087\end{array}$ & $\begin{array}{l}\text { Default Model should have } \\
\text { least ECVI value }\end{array}$ \\
\hline
\end{tabular}

Source: Author compilation [29].

Table 7. Structural equation modeling results.

\begin{tabular}{ccccccc}
\hline Relationship & $\begin{array}{c}\text { Unstandardized } \\
\text { Estimates }\end{array}$ & $\begin{array}{c}\text { Standardized } \\
\text { Estimates }\end{array}$ & S. E. & C. R. & $p$-value & R-Square \\
\hline WLBG <--- PYCP & 0.792 & 0.934 & 0.085 & 9.340 & 0.000 & 0.872 \\
\hline
\end{tabular}

Source: Author Compilation.

with well-being outcomes (positive health and distress) in management student populations.

Theoretically, it is evident from the literature that Psychological Capital is very much related to the well-being of the students in terms of engagement, positivity, stress handling, excellence in career, positive health etc. Numerous researchers confirmed significant causal relationship between Psychological Capital and academic engagement [12]; work engagement [9]; academic achievement [26]; life satisfaction [32]; experiencing positive emotions [33]; positive motivational orientation [34].

Moreover, the conservation of resources theory [35] hypothesizes that owning manifold psychological resources (like; hope, resilience, optimism, self-efficacy) would endow personalities to enthusiastically work on explicit professional goals and to accomplish well-being notwithstanding the ever-present encounters and difficulties in life.

Based on these theoretical assumptions, it seems that students would secure the psychological benefits of embracing Psychological Capital on pertinent school consequences because it could possibly augment their capability to prompt positive responses and vigorously take part in classroom or learning accomplishments. 


\section{Limitation and Future Avenues of Research}

Before explicating the contributions of the current work to existing psychological theory and practices, some limitations must be considered. First, we employed a cross-sectional design which may raise possible issues concerning the validity of the empirical results. It is highly recommended for further research works to use longitudinal designs to reinforce the claim regarding the relationship between Psychological Capital and student wellbeing.

Second, since this empirical research work relied on self-report data by the respondents to investigate the psychological benefits of Psychological Capital, further studies can make use of other data collection methods like; peer-reports and ratings given by instructors.

\section{Implications of the Study}

With limitations in the background, this study had contributed theoretically. The results confirmed the positive role of Psychological Capital in the academic context with reference to students' well-being. These results are consistent with the Psychological Capital theory and similar findings were recorded in Western contexts (Riolli et al., 2012), and Asian contexts, for instance China (Li et al. 2014).

Our study outcomes had some practical contributions. We strongly recommend that instructors, counselors, management and administration must work collectively on conceptualizing, planning, and execution of educational and counseling activities/programs that aim cultivate students' sustainable psychological resources like Psychological Capital to facilitate constructive psychological functioning in academics. A vital module of the program should involve longitudinal assessment on the constructive influence of Psychological Capital on success of students across all spheres. Implementation of Psychological Capital-oriented programs would thwart occurrence of major problems like; dropout, absenteeism, and even depression among them.

\section{Conflicts of Interest}

The authors declare no conflicts of interest regarding the publication of this paper.

\section{References}

[1] Li, B., Ma, H., Guo, Y., Xu, F., Yu, F. and Zhou, Z. (2014) Positive Psychological Capital: A New Approach to Social Support and Subjective Well-Being. Social Behavior and Personality: An International Journal, 42, 135-144. https://doi.org/10.2224/sbp.2014.42.1.135

[2] Luthans, F., Luthans, K.W. and Luthans, B.C. (2004) Positive Psychological Capital: Beyond Human and Social Capital. Business Horizons, 47, 45-50. https://doi.org/10.1016/j.bushor.2003.11.007

[3] Luthans, F., Avolio, B.J., Avey, J.B. and Norman, S.M. (2007) Positive Psychological Capital: Measurement and Relationship with Performance and Satisfaction. Per- 
sonnel Psychology, 60, 541-572. https://doi.org/10.1111/j.1744-6570.2007.00083.x

[4] Snyder, C.R., Harris, C. anderson, J.R., Holleran, S.A., Irving, L.M., Sigmon, S.T., Harney, P., et al. (1991) The Will and the Ways: Development and Validation of an Individual-Differences Measure of Hope. Journal of Personality and Social Psychology, 60, 570. https://doi.org/10.1037/0022-3514.60.4.570

[5] Scheier, M.F., Carver, C.S. and Bridges, M.W. (2001) Optimism, Pessimism, and Psychological Well-Being. Optimism and Pessimism: Implications for Theory, Research, and Practice, 1, 189-216. https://doi.org/10.1037/10385-009

[6] Masten, A.S. and Reed, M.G.J. (2002) Resilience in Development. In: Snyder, C.R. and Lopez, S.J., Eds., Handbook of Positive Psychology, Oxford University Press, New York, 74-88.

[7] Bandura, A. (1997) Self-Efficacy: The Exercise of Control. Freeman, New York.

[8] Beal III, L., Stavros, J.M. and Cole, M.L. (2013) Effect of Psychological Capital and Resistance to Change on Organizational Citizenship Behavior. SA Journal of Industrial Psychology, 39, 1-11. https://doi.org/10.4102/sajip.v39i2.1136

[9] Simons, J.C. and Buitendach, J.H. (2013) Psychological Capital, Work Engagement and Organizational Commitment amongst Call Centre Employees in South Africa. SA Journal of Industrial Psychology, 39, 1-12. https://doi.org/10.4102/sajip.v39i2.1071

[10] Avey, J.B., Reichard, R.J., Luthans, F. and Mhatre, K.H. (2011) Meta-Analysis of the Impact of Positive Psychological Capital on Employee Attitudes, Behaviors, and Performance. Human Resource Development Quarterly, 22, 127-152. https://doi.org/10.1002/hrdq.20070

[11] Luthans, F., Avey, J.B. and Patera, J.L. (2008) Experimental Analysis of a Web-Based Training Intervention to Develop Positive Psychological Capital. Academy of Management Learning and Education, 7, 209-221. https://doi.org/10.5465/amle.2008.32712618

[12] Siu, O.L., Bakker, A.B. and Jiang, X. (2014) Psychological Capital among University Students: Relationships with Study Engagement and Intrinsic Motivation. Journal of Happiness Studies, 15, 979-994. https://doi.org/10.1007/s10902-013-9459-2

[13] Keyes, C.L. (2014) Mental Health as a Complete State: How the Salutogenic Perspective Completes the Picture. In: Bridging Occupational, Organizational and Public Health, Springer, Berlin, 179-192. https://doi.org/10.1007/978-94-007-5640-3_11

[14] World Health Organization (2004) Promoting Mental Health: Concepts, Emerging Evidence, and Practice. World Health Organization, Geneva.

[15] Soutter, A.K., O'Steen, B. and Gilmore, A. (2014) The Student Well-Being Model: A Conceptual Framework for the Development of Student Well-Being Indicators. International Journal of Adolescence and Youth, 19, 496-520. https://doi.org/10.1080/02673843.2012.754362

[16] Noble, T., Wyatt, T., McGrath, H., Roffey, S. and Rowling, L. (2008) Scoping Study into Approaches to Student Well-Being. Report to Department of Education, Employment and Work Place Relations, Australian Catholic University and Erebus International, 1-77.

[17] Datu, J.A.D. and Valdez, J.P.M. (2016) Psychological Capital Predicts Academic Engagement and Well-Being in Filipino High School Students. The Asia-Pacific Education Researcher, 25, 399-405. https://doi.org/10.1007/s40299-015-0254-1

[18] Noble, T. and McGrath, H. (2011) The Third Pillar of the Student Well-Being Pedagogy: Positive Educational Practices. In: Teacher Education and Values Pedagogy: 
A Student Wellbeing Approach, David Barlow Publishing, New South Wales, 54-74.

[19] Macleod, A.K. and Moore, R. (2000) Positive Thinking Revisited: Positive Cognitions, Well-Being and Mental Health. Clinical Psychology \& Psychotherapy: An International Journal of Theory \& Practice, 7, 1-10. https://doi.org/10.1002/(SICI)1099-0879(200002)7:1<1::AID-CPP228>3.0.CO;2-S

[20] Luthans, F., Youssef, C.M., Sweetman, D.S. and Harms, P.D. (2013) Meeting the Leadership Challenge of Employee Well-Being through Relationship PsyCap and Health PsyCap. Journal of Leadership and Organizational Studies, 20, 118-133. https://doi.org/10.1177/1548051812465893

[21] Culbertson, S.S., Fullagar, C.J. and Mills, M.J. (2010) Feeling Good and Doing Great: The Relationship between Psychological Capital and Well-Being. Journal of Occupational Health Psychology, 15, 421. https://doi.org/10.1037/a0020720

[22] Roche, M., Haar, J.M. and Luthans, F. (2014) The Role of Mindfulness and Psychological Capital on the Well-Being of Leaders. Journal of Occupational Health Psychology, 19, 476. https://doi.org/10.1037/a0037183

[23] Gyu Park, J., Sik Kim, J., Yoon, S.W. and Joo, B.K. (2017) The Effects of Empowering Leadership on Psychological Well-Being and Job Engagement: The Mediating Role of Psychological Capital. Leadership and Organization Development Journal, 38, 350-367. https://doi.org/10.1108/LODJ-08-2015-0182

[24] Siu, O.L. (2013) Psychological Capital, Work Well-Being, and Work-Life Balance among Chinese Employees. Journal of Personnel Psychology, 12, 170-181. https://doi.org/10.1027/1866-5888/a000092

[25] Tripathi, P. (2011) Employee Well-Being: Role of Psychological Capital. Amity Journal of Applied Psychology, 2, 18-22.

[26] Luthans, B.C., Luthans, K.W. and Jensen, S.M. (2012) The Impact of Business School Students' Psychological Capital on Academic Performance. Journal of Education for Business, 87, 253-259. https://doi.org/10.1080/08832323.2011.609844

[27] Goldberg, D. and Williams, P. (1988) A User's Guide to the General Health Questionnaire. NFER-Nelson, Windsor.

[28] Nunnally, J. and Bernstein, I.H. (1994) Psychometric Theory. 3rd Edition, McGraw Hill, New York.

[29] Hair, J.F., Black, W.C., Babin, B.J., Anderson, R.E. and Tatham, R.L. (2010) Multivariate Data Analysis. 6th Edition, Pearson Prentice Hall, Upper Saddle River.

[30] Browne, M.W. and Cudeck, R. (1992) Alternative Ways of Assessing Model Fit. Sociological Methods and Research, 21, 230-258.

https://doi.org/10.1177/0049124192021002005

[31] Bagozzi, R.P. and Yi, Y. (1988) On the Evaluation of Structural Equation Models. Journal of the Academy of Marketing Science, 16, 74-94. https://doi.org/10.1007/BF02723327

[32] Riolli, L., Savicki, V. and Richards, J. (2012) Psychological Capital as a Buffer to Student Stress. Psychology, 3, 1202-1207.

https://doi.org/10.4236/psych.2012.312A178

[33] Murray, A.J., Pirola-Merlo, A., Sarros, J.C. and Islam, M.M. (2010) Leadership, Climate, Psychological Capital, Commitment, and Well-Being in a Non-Profit Organization. Leadership and Organization Development Journal, 31, 436-457. https://doi.org/10.1108/01437731011056452

[34] Luthans, F., Youssef, C.M. and Avolio, B.J. (2007) Psychological Capital: Developing the Human Competitive Edge. Oxford University Press, New York. 
[35] Hobfoll, S.E. (2001) The Influence of Culture, Community, and the Nested-Self in the Stress Process: Advancing Conservation of Resources Theory. Applied Psychology: An International Review, 50, 337-370. https://doi.org/10.1111/1464-0597.00062 